\title{
Els orígens i el desenvolupament de la Diputació del General del Regne de València
}

\author{
Laura Peris Bolta (laupebol@alumni.uv.es) \\ Universitat de València
}

\section{Introducció}

La Generalitat Valenciana ha commemorat recentment els seus sis segles d'història. La celebració de l'efemèride, amanida per l'excepcionalitat de la xifra, ha permés rescatar de l'oblit historiogràfic una institució clau per a entendre la complexitat de la història dels valencians i de les valencianes. Lentament, i seguint l'estel de puntuals però admirables treballs d'investigació publicats en els darrers temps, comencem a albirar la profunditat real d'aquella inicial Generalitat valenciana, la Diputació del General del Regne de València, tan diferent - fins i tot en el nom - a l'actual. El present article intenta aportar un poc de llum al moment de la seua institucionalització en el segle xv, amb l'objectiu d'entendre quin fou el paper de la Diputació del General envers la societat valenciana de la baixa edat mitjana.

Per a fer-ho, en primer lloc ens remetrem als orígens de la Diputació i a la seua evolució fins a consolidar-se com a institució permanent. Igualment, identificarem les particularitats que va adquirir en el moment del seu naixement, així com l'esquelet de la seua estructura atributiva, per tal de comprendre, d'una banda, el funcionament intern de la institució i la seua influència externa una vegada ja consolidada $i$, d'altra banda, quines funcions va adquirir de facto amb el pas del temps.

\section{Els orígens de la Diputació del General del Regne de València}

Els orígens de la Diputació del General del Regne de València s'han d'entendre en el context del canvi de política financera que es va donar al llarg de la baixa edat mitjana en alguns Estats de l'Europa medieval (Stasavage, 2011). En el marc d'unes guerres cada vegada més oneroses i llargues, a partir del segle XIV va tindre lloc un increment de les exigències reials, perquè els tributs i les rendes feudals que conformaven els recursos de la monarquia ja no eren suficients per a afrontar les urgències dels conflictes bèl·lics. Aquesta situació es va concretar en dues vies d'acció arreu d'Europa, amb importants mostres de precocitat en els territoris de la Corona d'Aragó. En primer lloc, es va produir la generalització de les càrregues fiscals a tots els habitants de cada entitat política, i no solament als vassalls directes del rei; i, en segon lloc, les institucions municipals van destacar com a agents recaptadors d'aquella nova i eixamplada fiscalitat. D'aquesta manera, va tindre lloc el naixement d'una fiscalitat d'àmbit general, coneguda amb el nom de «fiscalitat d'Estat», que es va desenvolupar durant el segle XIV de la mà de les Corts, amb la creació d'impostos sobre el consum per a satisfer les demandes del rei (Sánchez Martínez, 1995; Furió i Sánchez Martínez, 1996; García Marsilla, 2002; García Marsilla, 2006). 
Quan la Corona d'Aragó es trobava immersa en la guerra amb Castella (1356-1369), aquesta responsabilitat fiscal va ser assumida per les Corts de 1362-1363, data comunament acordada per la historiografia com la del naixement de la Diputació del General - no la seua oficialització com a institució permanent, sinó l'origen del que posteriorment esdevindria(Muñoz Pomer, 1987). Aquelles Corts van acceptar gestionar el donatiu atorgat al rei incorporant-hi un nou recurs fiscal: l'impost de les generalitats. Ja existia l'antecedent de comissions designades per les Corts per a fer complir els seus propis acords en matèria fiscal, però en un context bèlllic tan extens i exigent, les Corts van saber aconseguir, en negociació amb la Corona, una sèrie de drets: ara no solament estarien encarregades de la recaptació fiscal, sinó també de l'administració posterior (Baydal, 2011). Aquestes comissions reberen el nom de diputacions - i en serien tres: l'aragonesa, la valenciana i la catalana-, les quals donaren lloc posteriorment a les Diputacions del General - en referència a la globalitat d'estaments que unia- $\mathrm{o}$, en el cas concret dels valencians, la Diputació del General del Regne de València.

La institució també va acabar rebent el nom del principal impost que gestionava, anomenat generalitat perquè l'impost no reconeixia cap exempció personal, ja que ni tan sols el rei podia resultar, de dret, exempt de pagar les generalitats, com sí que ocorria amb altres impostos. En concret, inicialment les generalitats gravaven la importació i l'exportació de mercaderies al Regne de València, així com el consum d'aquestes en el seu interior. Les tarifes podien variar en el temps i entre si segons l'activitat i el tipus de productes, els quals s'agrupaven en capítols en funció de la recaptació i l'afinitat. Després d'un procés que va abastar diversos anys, les generalitats es van concretar durant el segle XV en deu capítols: l'impost sobre l'exportació de llana esquilada o encara per esquilar; de tints, d'espècies, de peix i de cendra; de diverses teles i mercaderies del regne; de pells d'animals, com el cuir o les pells de bestiar de llana; de la fusta i del vi; de l'arròs blanc i vermell; de les pells ja tractades per pellissers; de plata, nova o treballada; de la sal; i, finalment, l'impost del tall del drap sobre la fabricació, venda i exportació d'alguns teixits, en primer lloc, a València, en segon lloc, a Oriola i Guardamar i, en tercer lloc, a totes les ciutats, viles o alqueries restants. El tall del drap carregava la venda de teles de seda, llana, 1li, cotó, cànem i or, entre altres, així com la seua fabricació per a la venda posterior, la seua importació o exportació (Camarena, 1955; Muñoz Pomer, 1987; Muñoz Pomer, 2013).

Per a portar a terme un cobrament eficient dels impostos es va establir una divisió territorial del Regne de València en dos quarters generals, el de Tramuntana o Llevant, i el de Ponent, separats pel riu Xúquer. Cada un d'aquests es va dividir al seu torn en quarters al voltant de les principals ciutats $\mathrm{i}$ els seus termes, els quals estaven a càrrec d'un funcionari de la Diputació, que rebia el nom de subdelegat dels administradors. Així, a mitjan segle xv podem trobar el subdelegat d'Alzira, el de Xàtiva, el de Sogorb, el de Vilafermosa o el de Dénia, entre altres. La seua funció consistia a supervisar la recaptació d'impostos, generalment a càrrec d'un arrendador, és a dir, un comprador que havia adquirit de la Diputació el dret d'administrar determinats tributs durant el temps que estipulara el contracte. Aquesta transacció se solia fer mitjançant subhasta i generalment tenia lloc al voltant de la Llotja de València. En els casos en què la subhasta fracassava i no es trobava cap comprador, eren els mateixos subdelegats dels administradors qui portaven a terme el cobrament dels impostos (Muñoz Pomer, 1987). 
La recaptació dels donatius reclamava la necessitat de procediments fiscals consistents i les generalitats o drets del General van sumar-se a altres sistemes de recaptació com ara el compartiment, que consistia en el repartiment entre els tres braços de la recaptació del donatiu concedit al rei. Tanmateix, ben aviat es va evidenciar que la càrrega fiscal total era insuficient i que el grau d'exigència reial requeria urgentment la introducció d'un nou tipus de finançament. La solució va vindre amb l'emissió de deute públic. Amb els violaris, i sobretot amb els censals, les institucions de sobte es van trobar capacitades per a avançar capital al monarca en un termini de temps molt més reduït. Així, el que va començar com una solució de caràcter temporal va acabar esdevenint un pilar fonamental de l'economia estatal i privada valenciana (Furió, 1999; García Marsilla, 2002; García Marsilla, 2006).

\section{La consolidació de la Diputació del General: l'estructura interna i el deute públic}

Entre els anys 1403 i 1418 la Diputació del General del Regne de València va abandonar el seu estatus de comissió temporal de les Corts per tal de conformar en si mateixa una institució independent i de caràcter permanent que defugia el control reial (Muñoz Pomer, 1987). En concret, en les Corts de 1404 va adquirir l'esquelet de la seua estructura interna i les consegüents funcions que els nous càrrecs comportaven, mentre que en les Corts de 1418, ja en el regnat d'Alfons el Magnànim, va assolir la seua institucionalització permanent. El 22 de març de l'any 1418 els estaments del Regne de València, reunits en el convent de Sant Doménec, elegiren els sis primers diputats de la Diputació del General permanent: Hug de Llupià, bisbe de València, Romeu de Corbera, mestre de Montesa, Alfons d'Aragó, duc de Gandia, el cavaller Lluís Carbonell, el ciutadà de València Bernat Joan, i Bernat Costejà, veí d'Alzira (Ferrer i Urzainqui, 2007). Aquella estructura, dos diputats per estament, es mantindria inalterable fins la dissolució de la institució amb el Decret de Nova Planta l'any 1707 (Villamarín, 2005).

El caràcter permanent de la Diputació del General va arribar amb l'atribució feta als diputats d'elegir de manera automàtica, en el marc del nomenament dels oficials de la Generalitat, els seus successors per a la següent legislatura, un instrument essencial per a garantir la continuïtat temporal de tota la institució. Atés que la durada de l'exercici dels diputats era de tres anys, la institucionalització de la Diputació es va fer oficial l'any 1422, amb l'elecció de la segona sisena de diputats. Quedava així la gestió de la Diputació del General en les seues pròpies mans — de dret, legitimada permanentment - i començava a rodar el que seria una vida institucional particularment llarga.

De fet, amb la institucionalització de la Diputació, va sorgir la necessitat d'una seu pròpia i l'any 1421 els diputats llogaren dues habitacions d'una casa situada al carrer dels Cavallers de València. L'immoble, que es compraria sencer l'any següent, estava registrat a nom de Jaume Desplà, arxiver de l'Arxiu Reial del Real i escrivà de sala del Consell Municipal. A finals de segle, el 1481, es va adquirir també la casa contigua, que donava a l'actual plaça de Manises, i que contindria l'arxiu de la institució - que fins llavors mancava de seu-, la nova escrivania i l'escala de pedra de Pere Comte - que a principis del segle XVI seria reformada per Joan Corbera - i la capella. En els anys posteriors es van produir les reformes i la decoració de les grans sales, així com l'adquisició de nous immobles que finalment conformarien la reconeguda imatge de la Generalitat Valenciana 
actual, present en l'imaginari collectiu dels valencians i les valencianes de hui en dia (Martínez Aloy, 1920).

D'altra banda, per a poder extraure una imatge global de les funcions de la Diputació del General del Regne de València quan ja era una institució consolidada, convé observar-ne l'estructura interna. D'aquesta manera, s'hi poden detectar les funcions de la institució donades per dret, així com les que es van assumir de facto, que van ser les que posteriorment originarien, per exemple, una funció de representativitat política dels interessos dels valencians.

En aquest sentit, una vegada entrat el segle xv, la Diputació del General del Regne de València, de la mateixa manera que les seues homòlogues contemporànies, es trobava conformada per un cos d'oficials que desenvolupaven individualment l'exercici i funcions globals de la institució (Sesma, 1977; Sánchez de Movellán, 2004; Castillo del Carpio, 1993; Castillo del Carpio, 2013). Com ja s'ha assenyalat, aquest engranatge orgànic i administratiu havia anat mudant prèviament amb el temps i havia convertit les primeres diputacions temporals de raó fiscal i financera en una institució permanent consolidada a partir de les Corts del 1418. Caldria destacar, per tant, que, com altres atribucions de la mateixa institució, la seua estructura és més una conseqüència directa del quefer de les comissions que l'originaren i de les necessitats que aquestes detectaren, que d'una planificació sorgida del no-res.

Així, en primer lloc, en el cim de la jerarquia es trobaven els sis diputats, els quals constituïen la màxima autoritat en l'administració del General, una autoritat que es traduïa en la independència respecte d'altres poders i que atorgava credibilitat als diputats i a la institució. La seua funció principal era la mateixa que la de la Diputació en el moment de la seua institucionalització: el control i l'administració del donatiu al rei. Era responsabilitat dels diputats que les quantitats atorgades al monarca li foren lliurades en el termini establert. Ultra això, una vegada celebrades les Corts del 1418 i posteriorment les del 1428 , els diputats van anar guanyant més atribucions, fins que es van consolidar com el grup executiu de la institució.

Concretament, per a portar a terme la seua tasca principal i complir amb els serveis econòmics concedits al monarca, els corresponia autoritzar les despeses corrents de la Diputació del General i aprovar les transaccions financeres i econòmiques necessàries, com ara les emissions de censals i les operacions creditícies. En segon lloc, tenien l'obligació de designar els oficials subordinats —el síndic, l'assessor i l'escrivà-, així com establir-ne els salaris ordinaris. Per últim, tenien competència sobre els impostos de les generalitats per a arrendar-los, exigir-los per qualsevol via i procediment, especialment envers els morosos fiscals i estafadors, així com per supervisar-ne la recaptació, ja que comptaven, per acte de Cort, amb la jurisdicció privativa sobre els béns del General.

Els diputats eren sempre sis homes, dos en representació de cada braç i elegits en funció de criteris diferents. Els dos diputats del braç reial eren escollits per separat, un en representació de la ciutat de València, i l'altre pels jurats de la ciutat o vila reial a la qual li corresponguera durant aquell trienni. Els diputats del braç militar, juntament amb la resta d'oficials, eren seleccionats mitjançant el sistema de sac i sort, i en el cas dels diputats i dels jutges comptadors solia correspondre un membre per l'alta noblesa i un per la baixa noblesa. Finalment, els diputats del braç eclesiàstic eren elegits pels diputats ixents del 
mateix braç, amb un repartiment usual d'un diputat per al clergat secular i un per al clergat regular. Si un dels diputats no podia assistir a alguna reunió, podia fer cessió del càrrec a un substitut per a l'esdeveniment concret. Si l'absència es prolongava en el temps, el substitut podia acabar cobrant el salari en lloc del diputat elegit i, en casos de causa major o absència determinant, ser elegit com a nou diputat fins al final de la legislatura (Castillo del Carpio, 2013).

Seguint els diputats en ordre de jerarquia, es trobava el cos d'oficials de la Diputació del General del Regne de València. Entre aquests hi havia els administradors, un per cada braç, que tenien la potestat jurisdiccional al si de la Diputació i s'encarregaven de jutjar i fer resoldre totes les qüestions que sorgiren al voltant de les generalitats. Comptaven amb l'ajuda dels subdelegats dels administradors, elegits per a exercir la justícia en primera instància en matèria de la fiscalitat del General i supervisar l'arrendament de la recaptació dels impostos de primera mà, ja que situaven la seua residència als quarters de les ciutats principals. La seua presència per tot el territori del Regne de València va variar al llarg del segle xv. El 1425, per exemple, els administradors comptaven amb subdelegats a Morella, Vilafermosa, Onda, Borriana, Sogorb, Morvedre, Alzira, Xàtiva, Gandia i Oriola. Vint-i-cinc anys després, el 1450, només a Ademús, Vilafermosa, Sogorb, Alzira, Penàguila, Dénia i Cocentaina.

Per a desenvolupar amb correcció la seua tasca, la Diputació proveïa els administradors, entre d'altres, de segells oficials i d'un lloc on establir el tribunal d'aquesta a València. Amb el pas del temps, la potestat jurisdiccional dels administradors al si de la Diputació xocaria amb l'autoritat dels diputats, uns xocs que arribaren fins a finals del segle XVI, quan, en les Corts del 1585, es va prohibir explícitament la intervenció dels diputats en els juís de les causes de fraus que oficiaven els administradors (Mora de Almenar, 1625).

El cos d'oficials de la Diputació del General comptava també amb tres clavaris, encarregats de la gestió de les finances de la institució. Eren els receptors dels ingressos i portaven a terme els pagaments - tots els comptes anaven al seu nom propi i escrivien els comptes en primera persona-, dels quals duien el compte en llibres de clavaria on desglossaven l'exercici d'un any en dates i rebudes, és a dir, en despeses i ingressos. A cada un dels tres braços de les Corts li corresponia un clavari, però a principis del segle XV es va evidenciar que el clavari del braç reial efectuava en la pràctica l'exercici diari de les competències del càrrec. Per aquesta raó, se'l va acabar nomenant «clavari rebedor de les pecúnies del General»; es van formalitzar de dret les seues atribucions, es concentraren en la seua persona les funcions de tota la clavaria i els clavaris del braç nobiliari i el braç eclesiàstic passaren a tindre un càrrec de caràcter nominatiu, fins que van desaparèixer. La importància de les atribucions del clavari per al correcte funcionament de la institució es reflectia en el seu salari: a mitjan segle xv, el clavari del braç reial o clavari del General cobrava 1.500 sous per l'exercici del càrrec, mentre que els diputats en cobraven 1.000.

La documentació que creava el clavari, tant els albarans com els llibres de clavaria, era sotmesa periòdicament a l'escrutini dels jutges comptadors, o comptadors del General. Fiscalitzaven la comptabilitat, examinant els comptes quadrats pel clavari i marcant en la documentació totes aquelles observacions que consideraven. En aquest sentit, tenien la potestat d'impugnar pagaments o cobraments si ho trobaven pertinent. Finalment, igual que els diputats, els jutges comptadors també n'eren sis, dos per cada braç (Castillo del Carpio, 2013). 
En un nivell per davall d'aquesta primera línia es trobaven els oficials subalterns, que no disposaven del poder de decisió dels anteriors però eren igualment importants $i$ necessaris per al funcionament de l'administració. També es diferenciaven dels primers perquè eren elegits directament pels diputats i l'exercici del seu càrrec era vitalici. Així, en aquest segon nivell d'oficials hi havia, en primer lloc, els escrivans de la Diputació, que s'encarregaven de deixar constància de tot procediment o acció que tenia lloc al si de la institució, mitjançant l'elaboració dels llibres d'actes, els llibres de clavaria, els contractes, la redacció de la correspondència i un llarg etcètera. A principis del segle Xv hi havia dos escrivans: l'escrivà dels diputats i l'escrivà dels administradors, però al llarg del segle acabà per haver-n'hi solament un: l'escrivà del General. Aquest oficial, que solia ser un notari, podia cobrar fins a 800 sous anuals com a salari base, més un salari extraordinari que alguns anys podia arribar fins a 500 sous més, en concepte de lletres missives per causes sobrevingudes dirigides al rei, altres Diputacions o càrrecs estrangers, per posar-ne només alguns exemples (Muñoz Pomer, 1987; Castillo del Carpio, 2013).

Al costat dels escrivans es podia trobar també l'assessor de la Diputació del General. L'assessor, o advocat, assistia la institució en matèria jurídica i legal. En aquest sentit, un exemple del caràcter vitalici del càrrec fou el de Gabriel de Palomar, qui durant la primera meitat del segle xv, des del 1422 fins al 1450, va ser l'assessor de la Diputació del General, el segon en ordre cronològic des de la seua institucionalització.

Per últim, tancaven el cos dels oficials els porters de la Diputació del General, les funcions dels quals sovint es compartien amb els verguers i fins i tot es van arribar a confondre en algun exercici. El seu treball consistia fonamentalment a complir o fer complir els encàrrecs menors que els diputats o altres oficials majors els encomanaven. Aquests encàrrecs solien incloure des de la compra de materials per a algun servei a la Diputació fins al lliurament de missatgeria oficial o l'acompanyament d'algun càrrec que es desplaçava en representació de la Diputació, motiu pel qual tenien també la facultat d'administrar els diners del General - sempre amb la supervisió del clavari- (Castillo del Carpio, 2013).

Més enllà del cos d'oficials que constituïa el gros del funcionariat de la Diputació del General, la institució comptava amb contractacions extraordinàries però de caràcter recurrent, que es repetien exercici rere exercici. Aquests oficis amb vinculació freqüent a la Diputació del General del Regne de València eren diversos. D'una banda, els dedicats a les tasques auxiliars d'oficials de la institució, com eren els porters de caràcter extraordinari els quals s'encarregaven de faenes molt concretes encomanades pels diputats o altres oficials de la institució, com ara el pagament d'alguns contractes puntuals o l'acompanyament d'oficials fora de València- i els notaris escrivans, qui habitualment ajudaven l'escrivà del General fent-se càrrec de l'escriptura de llibres sencers - potser un treball massa ardu per a compaginar-lo amb el treball diari de l'escrivà del General- o confeccionant documentació molt concreta, de caràcter extraordinari o elaborada en altres ciutats més enllà del Cap i Casal.

D’una altra banda, també hi havia l'hoste de correus, encarregat de fer arribar les missives dels diputats valencians als receptors pertinents mitjançant la subcontractació de correus o troters i de rebre les missives dirigides a la institució - motiu pel qual generalment l'hoste de correus era també un hostaler- i, així mateix, també treballaven recurrentment per a la Diputació diferents corredors, que durant el segle xv solien ser corredors d'orella 
o corredors cridadors. Els primers feien d'intermediaris entre la Diputació del General i les altres parts en cas d'una compravenda o préstec; els segons també eren coneguts com a corredors de coll, ja que s'encarregaven de les subhastes i crides relacionades amb les compres i les vendes. A més a més, aquests corredors de coll sovint també exercien de corredors de trompeta, ja que convocaven les subhastes amb el toc d'aquell instrument; en relació amb açò, ens trobem amb un llinatge de corredors de trompeta de la Diputació perpetuat en l'ofici - una pràctica comuna en moltes altres institucions - en el cas concret de la família Artús, que el 1425 tenia com a trompetes Llorenç i Ramon Artús, mentre que vint-i-cinc anys després hi exercia el mateix ofici Miquel Artús.

Finalment, l'activitat diària de la Diputació del General s'acabava per conformar amb la contractació de comerciants i artesans de la ciutat de València per a encàrrecs puntuals, com ara llibreters per a aconseguir tinta, pergamins o lligaments de llibres, apotecaris per a obtindre cera, botiguers per a aconseguir paper, sabaters per al calcer dels oficials, obrers per a arreglar els desperfectes del palau o, fins i tot, un fuster que el 1450 era contractat per a fer els cadafals del Corpus pagats per la institució.

En aquest sentit, la Diputació del General del Regne de València va anar durant el segle XV molt més enllà de les funcions inicialment atribuïdes als membres que la integraven, ja que va assolir un major grau de complexitat gràcies a dos factors principals. D’un costat, la funció de representativitat política que la institució va anar adquirint al llarg de la centúria - manifestada, per exemple, en les actes de les reunions o les relacions epistolars que mantenia - va sobrepassar en moltes ocasions l'àmbit estricte de la Diputació, una prova del fet que els diputats disposaven d'una certa influència i presència en la societat valenciana del moment. En concret, la representativitat de la Diputació era una cara més d'un panorama polític i social complex en què les Corts o el Consell municipal de València també exercien un paper important. En tot cas, l'afirmació que la Diputació del General podia arribar a representar els interessos del Regne de València no és desgavellada si la situem en el context adequat, és a dir, en relació amb les altres institucions o agents polítics de la realitat medieval.

D’una altra banda, l'emissió de deute públic per part de la Diputació del General va permetre que la institució acabara esdevenint un dels tres caps principals de les finances de l'Estat, al costat de la ciutat de València i en menor mesura de la Batlia General (Furió, 1999; López Rodríguez, 2001; García Marsilla, 2006). Fonamentalment, l'entrada en el mercat del crèdit per part de la Diputació es va fer mitjançant els censals. El censal consistia en una renda, normalment en capital metàl-lic, que es rebia al llarg del temps a canvi del lliurament immediat d'una quantitat superior de diners. El prestador comprava el dret a rebre una renda anual per part del prestatari, qui es trobava en necessitat d'una quantitat concreta de sous, la qual ingressava en concepte de la compra.

En el cas de la Diputació del General del Regne de València, com que per a satisfer el donatiu del rei es necessitaven capitals líquids amb urgència, es produïa un endeutament a perpetuïtat amb persones concretes que donaven al moment les quantitats necessàries. En aquest sentit, era a perpetuïtat perquè el deute solament es podia cancel·lar si la Diputació retornava en un sol pagament la quantitat inicialment prestada - cosa molt improbable - i fins que no ho fera la institució restava obligada a pagar un interés anual, conegut com a pensió de censal, que va arribar a constituir una mena de renda per a l'oligarquia del regne. 
En consequiència, si bé era cert que així, amb les quantitats rebudes, es podien satisfer les exigències reials immediatament, també ho era que encara restaven per pagar, any rere any, els interessos dels nous deutes adquirits. Per aquest motiu la institució es va veure obligada a emetre nous censals per a pagar els interessos dels anteriors i així consecutivament, fins que a finals del regnat d'Alfons el Magnànim tres quartes parts de les despeses totals de la institució es destinaven ja a satisfer el deute amb els censalistes.

És menester, però, incidir en la idea que l'existència d'aquest deute sobrevingut, que historiogràficament ha conduït a considerar la Diputació del General com una institució insolvent, en realitat no reflectia una situació tan descontrolada ni d'una gravetat tan patent com s'ha percebut de manera tradicional. En efecte, la Diputació es trobava endeutada, com ho estaven altres institucions del moment, però el deute no l'anul-lava com a institució, sinó que la va convertir en un òrgan emissor de deute públic a escala molt notable. De fet, en la mentalitat baixmedieval, al deute no sempre se li associava una càrrega negativa potent, com sí que es pot fer en l'actualitat, sinó que formava part de la quotidianitat (García Marsilla, 2002). En aquell marc cognitiu que es trobava a cavall entre la mercantilització de la societat i les arrels feudals, el censal conjugava el concepte de renda, fonamentalment feudal, amb el de préstec, tan vinculat a la usura i tan condemnat per alguns religiosos. És a dir, que va suposar una adaptació als nous temps sense la recança dels vells. No s'entén sinó l'èxit absolut del censal com a recurs habitual i transversal en la societat valenciana, que va arribar a ser entés com una manera de mantindre segur part del patrimoni familiar i que aquest, amb el temps, arribara a generar algun benefici (Furió, 1999). En aquell context, la Diputació del General va ser acceptada amb total confiança per part del mercat del crèdit, una cosa que indica la gestió conscient i responsable dels seus oficials, la qual al seu torn millorava les condicions de la institució respecte del mercat del crèdit, sobretot a l'hora de carregar nous censals.

Tot i així, també convindria destacar que entre els censalistes amb els quals estava endeutada la Diputació hi havia un notori nombre d'oficials de la mateixa institució, per la qual cosa és lògic pensar que la gestió responsable del deute per part dels oficials implicava al seu torn la satisfacció de les seues pròpies rendes personals i que la motivació de la primera vinguera donada per la segona. En consequiència, es pot concloure que, tot buscant la seua supervivència, la Diputació del General va cobrar la suficient importància com a font d'ingressos de l'oligarquia urbana i nobiliària de València com perquè aquesta acabara ocupant el seu organigrama. Per tant, no és difícil deduir que en realitat la institució no estava solament al servei de la Corona, sinó que també era un instrument al servei dels interessos oligàrquics (Sáiz, 2008; Bernabeu, 2016).

En aquest sentit, l'emissió de censals va permetre a la Diputació del General ampliar la seua influència directa sobre la societat valenciana, així com estendre-la al llarg de la Corona d'Aragó. Per exemple, durant el regnat d'Alfons el Magnànim es podien trobar censalistes de València i ciutats properes - com Sagunt, Silla, Montcada o Godella-, d'altres ciutats i viles del regne - com Gandia, Castellfabib, Xàtiva, Corbera o Castelló de la Plana- o fins i tot d'indrets més llunyans com Barcelona i Sicília. A més a més, la transversalitat de l'espectre social i professional de l'emissió del deute públic es feia evident en el cos de censalistes de la Diputació del General, format per nobles com el duc de Gandia i altres membres de llinatges de l'alta noblesa, viudes apoderades, cavallers, donzells, 
ciutadans, mercaders, artesans, metges, notaris, canonges, preveres, monges, llauradors o dones que es volien assegurar el futur a consciència. En tot cas, l'adquisició del deute públic de la Diputació es va concentrar fonamentalment en aquells més enriquits, ja que al cap i a la fi perquè es poguera percebre una pensió notable es requeria també l'aportació d'una quantitat important de capital, atés que la pensió de censal al Regne de València durant el segle XV solia ser d'un interés reduït, en comparació amb el d'altres territoris.

En relació amb tot això, l'emissió de deute públic a la Corona d'Aragó cobra importància si la contrastem amb el panorama europeu, ja que per exemple a Anglaterra, epítet del parlamentarisme, no va arribar fins molt més tard. De fet, la Corona d'Aragó fou un dels territoris pioners en l'emissió de deute públic, propi d'aquelles finances d'Estat que es desenvoluparen en la baixa edat mitjana i que acceleraren l'evolució i la sofisticació dels anomenats Estats moderns. Entendre açò permet situar la institució que ens ocupa en una nova perspectiva.

\section{Conclusions}

Al llarg del segle xv la Diputació del General del Regne de València, dotada d'una estructura interna que en garantia la perpetuació i el bon funcionament, es va consolidar com a institució permanent encarregada d'administrar una important càrrega fiscal del Regne i d'emetre deute públic a una escala considerable. Aquest caràcter permanent es va assolir amb l'objectiu d'evitar-ne el control reial i d'adquirir més autoritat política, com de fet va succeir. Tot plegat, la Diputació del General formava part d'un mateix sistema de construcció d'un Estat políticament i institucionalment plural, propi de la Corona d'Aragó i similar a altres experiències com la d'Anglaterra, en contraposició amb el centralisme absolutista d'altres territoris com Castella i França.

És, per tant, innegable que la Diputació del General va constituir un instrument molt valuós per al monarca i per a les finances d'un Estat en el qual les elits estamentals complien un important paper polític i econòmic. També ho va ser, de fet, per a aquella oligarquia, especialment l'oligarquia urbana, que a mitjan segle xv ja emprava també la institució per a enriquir-se, mantindre a bon recer el patrimoni propi i poder engreixar el seu currículum polític.

\section{BIBLIOGRAFIA}

BAYDAL, V. (2011): Els fonaments del pactisme valencià. Sistemes fiscals, relacions de poder i identitat col-lectiva al Regne de València (c. 1250 - c. 1365), Barcelona, Universitat Pompeu Fabra, tesi doctoral.

Bernabeu, S. (2016): «L'oligarquia municipal de la ciutat de València durant el Regnat d'Alfons el Magnànim i Joan II (1416-1479)», Iradiel, P., G. Navarro Espinach, D. Igual i C. Villanueva (coords.), Identidades urbanas Corona de Aragón-Italia. Redes económicas, estructuras institucionales, funciones políticas (siglos XIV-XV), Saragossa, Prensas de la Universidad de Zaragoza, 93-113.

Camarena, J (1955): «Función económica del General del Regne de Valencia en el siglo XV», Anuario de historia del derecho español, 25, 529-542.

Castillo del Carpio, J. M. (1993): La Diputación de la Generalidad Valenciana en un periodo de crisis (1510-1527), València, Universitat de València, tesi de llicenciatura. 
Castillo del Carpio, J. M. (2013): La Generalitat Valenciana durante el siglo XVI: su estructura burocrática, sus competencias y sus hombres, València, Publicacions de la Universitat de València.

FERrer, R. I URZAINQUi, S. (eds.) (2007): Libre de diverses ordinacions fetes per los diputats del General del Regne de València, València, Generalitat Valenciana.

Furió, A. (1999): «Deuda pública e intereses privados. Finanzas y fiscalidad municipales en la Corona de Aragón», Edad Media: revista de historia, 2, 35-80.

Furió, A. I M. SÁnchez Martínez (1996): «Fiscalidad y sociedad en la baja edad media», Noticiario de historia agraria: Boletín informativo del seminario de historia agraria, 11 (6), 187-189.

García Marsilla, J. V. (2002): Vivir a crédito en la Valencia medieval. De los orígenes del sistema censal al endeudamiento del municipio, València, Publicacions de la Universitat de València.

García Marsilla, J. V. (2006): «Avalando al rey. Préstamos a la Corona y finanzas municipales en la Valencia del siglo XV», Fiscalidad de Estado y fiscalidad municipal en los reinos hispánicos medievales, Madrid, Casa de Velázquez.

LóPEZ RodríGuEZ, C. (2001): «Hisenda reial i comerç en el Regne de València en l'època del Magnànim», Recerques, 43, 129-161.

Martínez Aloy, J. (1920): La Casa de la Generalitat del Regne de València, València, Editorial Valenciana.

Mora de Almenar, G. R. (1625): Volum e recopilació de tots els Furs e actes de Cort que tracten dels negocis y affers respectants a la Casa de la Deputació y Generalitat de la Ciutat y Regne de València, en execució del Fur 83 de les Corts del any MDCIIII, València, Felip Mey.

Muñoz Pomer, M. R. (1987): Orígenes de la Generalidad Valenciana, València, Generalitat Valenciana.

MuÑoz Pomer, M. R. (2013): «La consolidación de la Generalidad Valenciana: élites y deuda pública», M. I. Falcón (coord.), El compromiso de Caspe (1412), cambios dinásticos y constitucionalismo en la Corona de Aragón, Saragossa, Ibercaja - Gobierno de Aragón, 560-570.

Sáiz Serrano, J. (2008): Caballeros del rey: Nobleza y guerra en el reinado de Alfonso el Magnánimo, València, Publicacions de la Universitat de València.

SÁnchez Martínez, M. (1995): El naixement de la fiscalitat d'Estat a Catalunya (segles XII-XIV), Vic, Eumo editorial - Universitat de Girona - Estudis Universitaris de Vic.

Sánchez de Movellán, I. (2004): La Diputació del General de Catalunya (1413-1479), Barcelona, Generalitat de Catalunya - Institut d'Estudis Catalans.

Sesma Muñoz, J. Á. (1977): La Diputación del Reino de Aragón en la época de Fernando II: (1479-1516), Saragossa, Institución Fernando el Católico.

Stasavage, D. (2011): States of credit. Size, power and the development of European polities, Princeton - Oxford, Princeton University Press.

VILlamarín, S. (2005): La Generalitat valenciana en el siglo XVIII. Una pervivencia foral tras la Nueva Planta, València, Publicacions de la Universitat de València.

\section{BIONOTA}

\section{Laura Peris Bolta}

És graduada en Història per la Universitat de València i compta amb els màsters de la mateixa universitat en Història de la Formació del Món Occidental i en Patrimoni Cultural. Amb el treball de final de màster del primer va començar l'estudi de la Diputació del General del Regne de València durant el segle $\mathrm{Xv}$, investigació que ha anat creixent fins a constituir el tema central de la seua tesi doctoral, iniciada recentment i que engloba una perspectiva financera i política de la institució, a més de la fiscal, en relació amb la construcció de l'Estat i l'emissió de deute públic. Es troba interessada, a més, en l'estudi dels sentiments identitaris i la història de gènere. 